\title{
МЕТОДИ ФІЗИЧНОГО ВИХОВАННЯ
}

\author{
Худолій O.M. \\ Харківський національний педагогічний університет імені Г.С. Сковороди
}

Анотація. У статті розглядаються загальні підходи до визначення класифікації методів, які використовуються у фізичному вихованні. Дана характеристика методу фізичної вправи.

Ключові слова: метод, метод фізичної вправи, суворо-регламентованої вправи, змагальний і ігровий.

Актуальність. Методи $є$ однією із складових навчального процесу. Єдиної науково обгрунтованої класифікації методів, які використовуються в педагогічному процесі не існує.

Способи впливу вчителя на учнів, способи роботи учнів - усе це відноситься до методів (у перекладі з грецької- спосіб, шлях) і методичних прийомів.

Метод - ие система дій вчителя в процесі викладання, тасистема дій учня у засвоєнні навчального матеріалу.

Відповідно до дидактичного завдання й умов фізичного виховання кожен метод реалізується за допомогою методичних прийомів, що входять до складу даного методу.

Методичний прийом - ие спосіб реалізацї методу відповідно до конкретного завдання фізичного виховання.

Отже, усередині кожного методу використовуються його різноманітні методичні прийоми. Поза методом прийом утрачає своє значення. Прийом дозволяє застосувати відповідний метод у конкретних умовах. При тому самому методі реалізація його може здійснюватися різними прийомами. Саме тому той чи інший метод використовується у рішенні найрізноманітніших дидактичних завдань на будь-якому етапі навчання і у роботі з будь-яким контингентом дітей. Причому, чим багатший запас методичних прийомів, тим ширше діапазон застосування методу. У той самий час кожен методичний прийом використовується тільки в окремих випадках і застосовується набагато рідше чим метод.

Спеціальну систему методів, методичних прийомів фізичного виховання, форм організації занять, засобів, створену для реалізації завдань фізичного виховання визначеним складом учнів прийнято називати методикою.
На думку Ю.В. Васькова [3] на уроках фізичної культури необхідно використовувати не тільки специфічні методи фізичного виховання, а й загальнодидактичні.

Отже, проблема систематизації методів, які використовуються у фізичному вихованні $\epsilon$ актуальною.

Зв'язок роботиз науковими програмами, темами. Робота виконана згідно плану наукових досліджень кафедри ТМФВ Харківського національного педагогічного університету імені Г.С. Сковороди.

Мета роботи - систематизувати методи, які використовуються у фізичному вихованні різних груп населення.

Методи дослідження. Для вирішення поставлених завдань були використані в процесі аналізу літератури як філософські, так і загальнонаукові методи дослідження, серед яких:

- діалектичний метод (принцип історизму, принцип системності, принцип діалектичного протиріччя, принцип єдності якості і кількості, принцип діалектичного заперечення, принцип розвитку, приннцип причинності);

- системний підхід;

- узагальнення, аналіз, синтез.

Класифікація методів фізичного виховання

Класифікації методів фізичного виховання - це упорядкована їх система за визначеною ознакою. 
У науково-методичній літературі із загальної педагогіки найбільш обгрунтовані такі класифікації методів:

- традиційна, в основі якої лежить практика, наочність і слово;

- за призначенням (М.А. Данилов, Б.П. Есипов [2]);

- по типу пізнавальної діяльності (И.Я. Лернер, М.Н. Скаткин [5]);

- по дидактичним цілям (Г.И. Щукина [14]);

- бінарні і полінарні класифікації (М.И. Махмутов [8]; В.Ф. Паламарчук [9]; Л. Клингберг [4]);

- класифікація методів за Ю.К. Бабанским [1].

Але, на думку И.П. Подласого [10], кожна з класифікацій має недоліки, так як багатовимірність методів їх взаємопроникнення набагато складніші ніж запропоновані абстрактні схеми.

Одна з останніх тенденцій у класифікаціїметодів - це відмовлення від надуманих побудов і перехід до простого перерахування методів. Такий підхід міститься в підручниках і навчальних посібниках 3 теорії і методики фізичного виховання Б.М. Шияна [13], Л.П. Сергієнка [12] (див. рис. 1, 2).

Аналіз підручників і навчальних посібників дозволив встановити, що методи у фізичному вихованні виконують такі функції:

- навчання;

- розвитку;

- виховання;

- мотивації;
- контролю і корекції.

Функціональний підхід $є$ основою для створення системи методів, в якій вони виступають як відносно обособлені способи досягнення цілей фізичного виховання.

Ю.Ф. Курамшин, В.В. Петровский [11], використовуючи функціональний підхід, пропонують класифікувати методи фізичного виховання за спрямованістю на:

1) придбання знань;

2) оволодіння руховими уміннями і навичками;

3) удосконалення рухових навичок і розвиток рухових здібностей (див. рис. 3);

4) нормування і управління навантаженням (див. рис. 4).

Основним методом фізичного виховання є метод фізичної вправи, так як фізична вправа $\epsilon$ вирішальним не лише засобом, а й способом досягнення мети фізичного виховання. Формування методу фізичної вправи історично йшло по трьом напрямкам, у результаті склалися три типи методів: суворо-регламентованої вправи, ігровий і змагальний. Відношення до цих методів у різних системах фізичного виховання довгий час мало тенденцію до невиправданого протиставлення (у ряді європейських країн, наприклад, недооцінювався змагальний метод, а в деяких американських країнах - методи суворо регламентованої вправи). У цьому зв'язку принципово важливо виходити з того, що жоден метод, яким би гарним він не був сам по собі, узятий у відриві від інших, не може розглядатися як

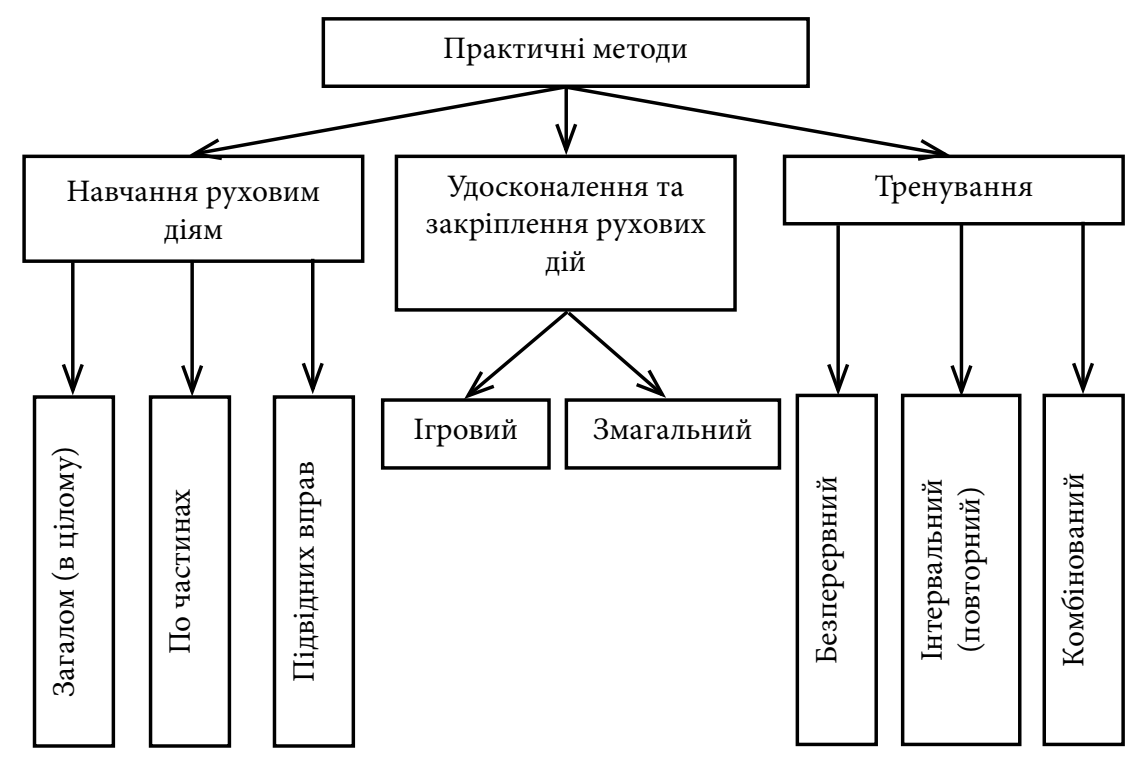

Рис. 1. Система практичних методів фізичного виховання (За: Б.М. Шиян, 2001) 


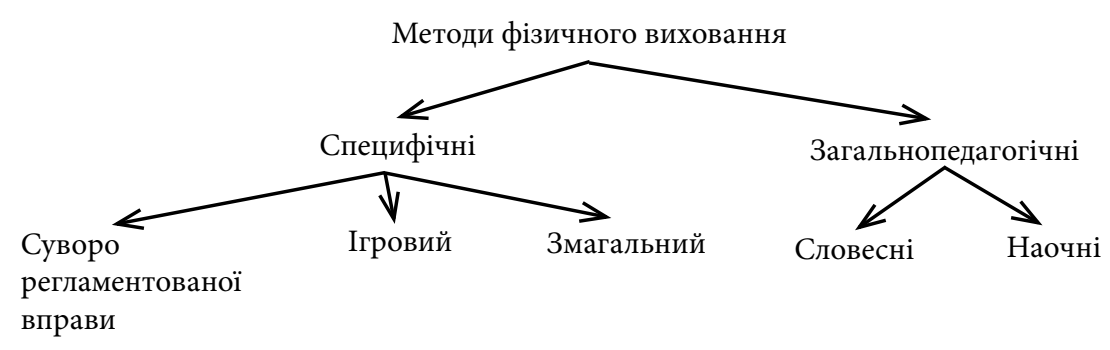

Рис. 2. Система практичних методів фізичного виховання (За: Л.П. Сергієнко, 2006)

Методи, які використовуються в процесі

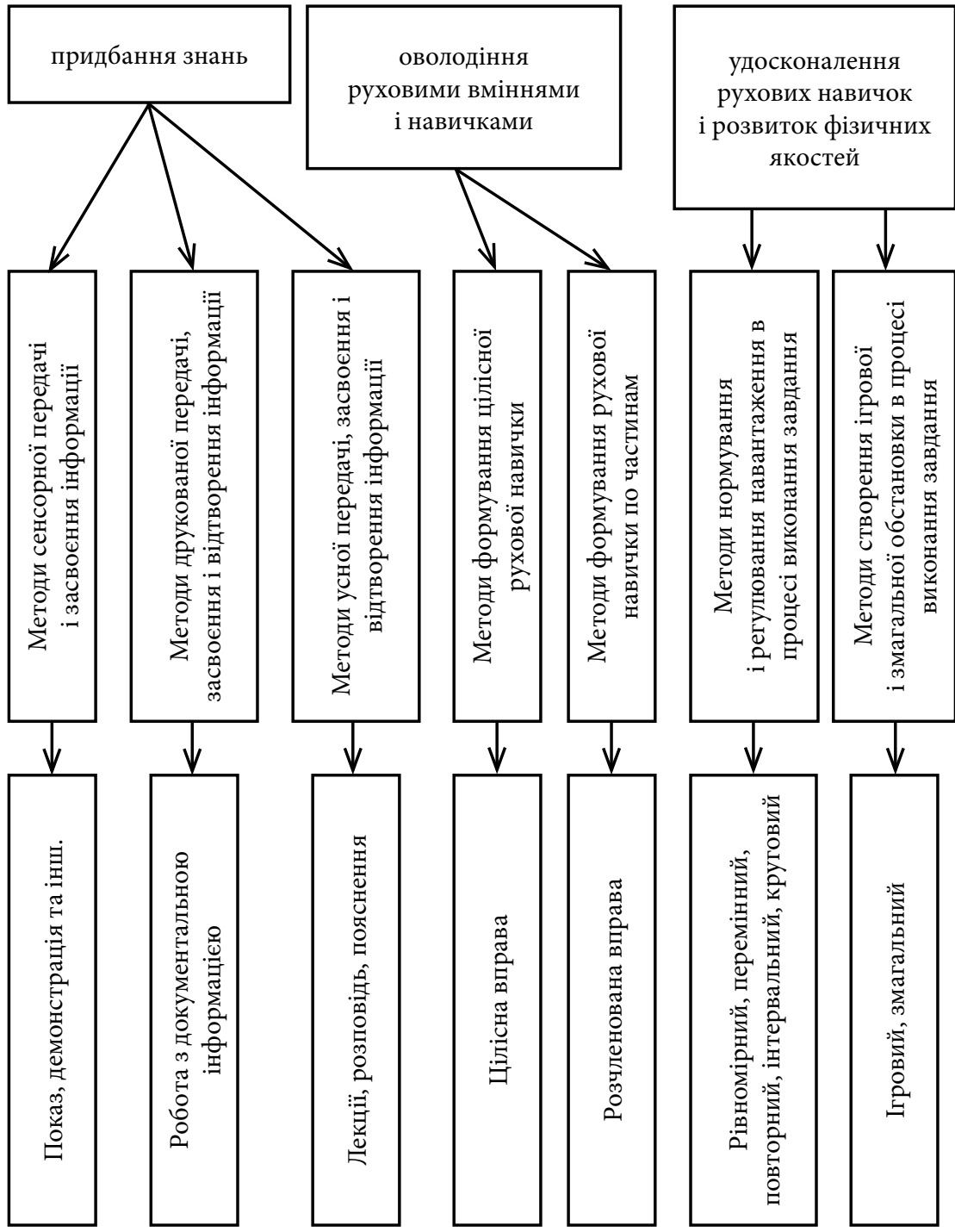

Рис. 3. Класифікація методів, які використовуються в процесі навчання руховим діям і розвитку фізичних якостей (за: Ю.Ф. Курамшиным, В.В. Петровским, 2003) 


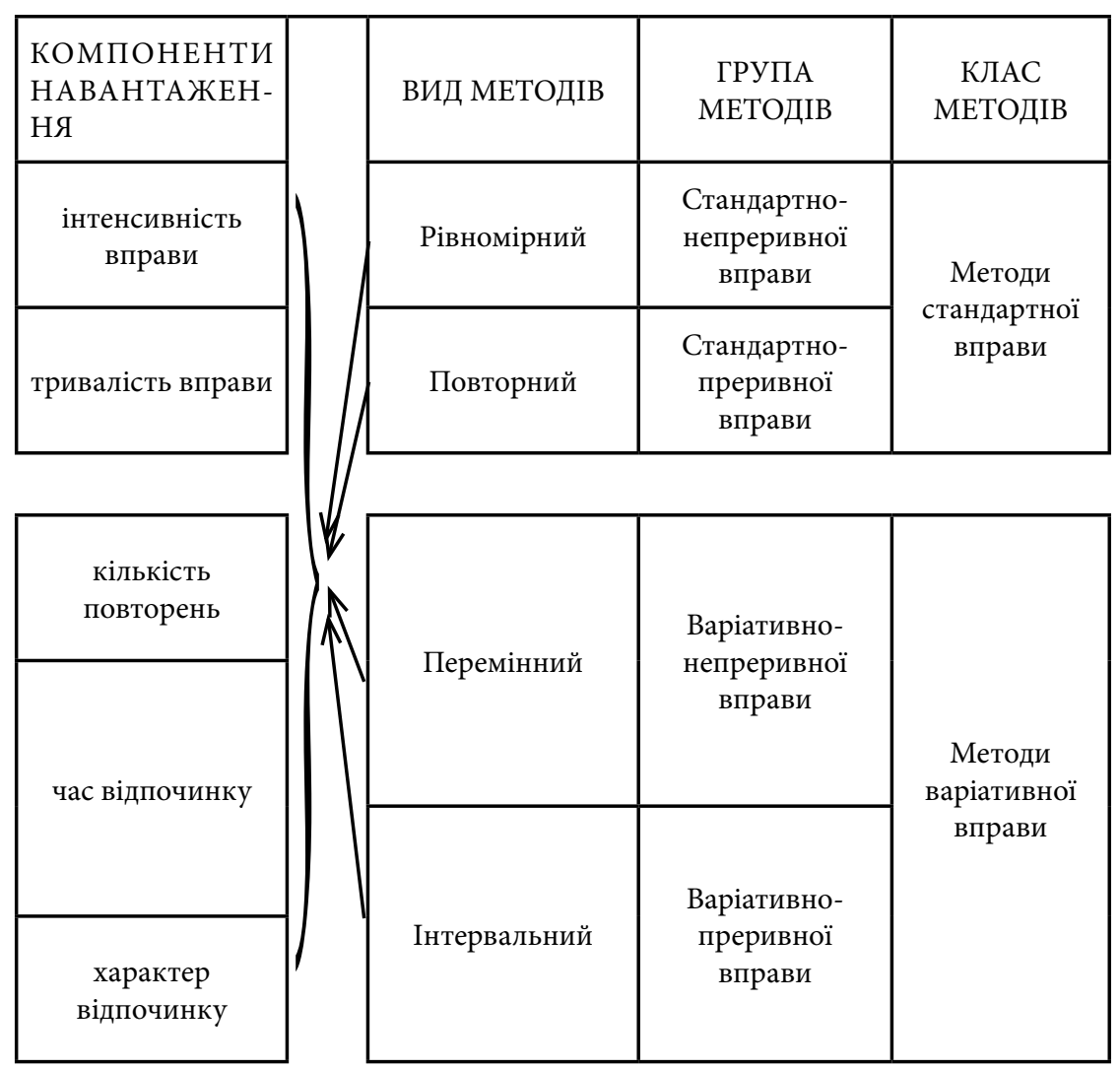

Рис.4. Класифікація методів, які використовуються для нормування і управління навантаженням у процесі виконання рухових дій (За: Ю.Ф. Курамшиным, В.В. Петровским, 2003)

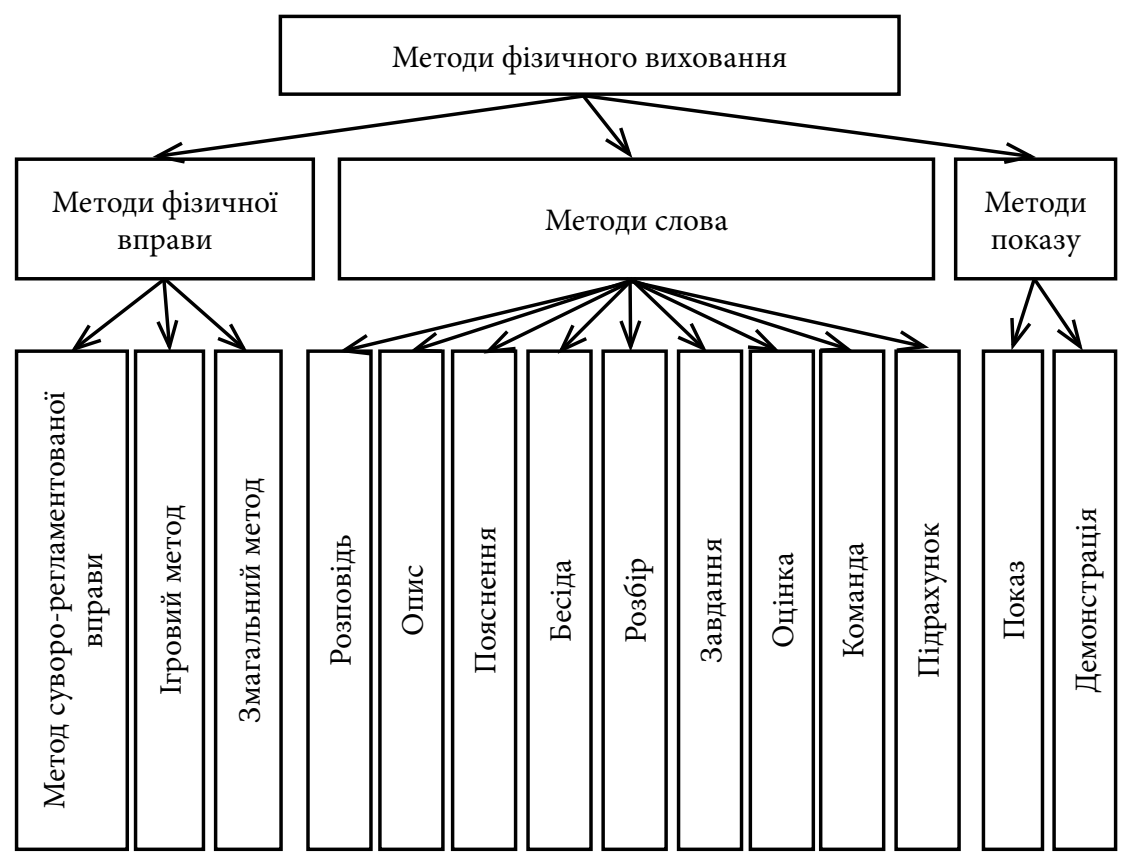

Рис. 5. Класифікація методів, які використовуються у фізичному вихованні 
єдино повноцінний. Лише сукупність методів, які використовуються відповідно до методичних принципів, може забезпечити успішну реалізацію комплексних задач фізичного виховання.

Отже методи, які використовуються у фізичному вихованні можуть бути розподілені на три групи: методи фізичної вправи, методи слова і методи показу (рис. 5). Методи фізичної вправи будуть розглянуті нижче.

\section{Методи суворо- регламентованої вправи}

Методами цього типу діяльність учнів організується і регулюється 3 можливо повною регламентацією, що складається:

- у запропонованій програмі рухів (заздалегідь обумовлені склад рухів, порядок їхнього повторення, зміни і зв'язки один з одним);

- у можливо точному нормуванні навантаження і керуванні його динамікою по ходу вправи, а також у нормуванні інтервалів відпочинку і суворо встановленому чергуванні їх з фазами навантаження;

- у створенні чи використанні зовнішніх умов, що полегшують керування діями учнів (шикування і розподіл групи на місцях занять, використання допоміжних снарядів, тренажерів і інших технічних пристроїв, що сприяють виконанню навчальних завдань, дозуванню навантаження, контролю за його впливом і т.д.).

Зміст такої регламентації зрозумілий: забезпечити оптимальні умови для освоєння нових рухових умінь, навичок і (чи) гарантувати точно спрямований вплив на розвиток рухових здібностей.
Методи суворо-регламентованої вправи мають безліч конкретних варіантів, вибір яких для застосування залежить від змісту занять, етапів (періодів), що послідовно змінюються в процесі фізичного виховання й інших обставин (рис. 6).

У процесі розучування рухових дій використовується повторний метод 3 ординарним (на етапі розучування) і напруженим (на етапі удосконалення) інтервалом відпочинку (табл. 1, 2). У залежності від групи вправ, які використовуються в процесі навчання, метод має наступну предметну інтерпретацію (методу присвоюються семантичні ярлики):

- метод цілісного навчання;

- метод розчленованого навчання;

- метод вирішення окремих рухових завдань;

- метод підвідних вправ;

- метод поєднання (сполученої дії);

- метод термінової і поточної інформації про точність рухів, які виконуються учнем.

Особливе значення в процесі удосконалення рухових навичок має метод поєднання (В.М. Дьячков), який спрямований на розвиток рухових здібностей у відповідності до структури основної вправи.

Стандартизація і варіювання дії в методах вправи. За цією ознакою методи суворо-регламентованої вправи підрозділяються на дві протилежні групи: 1) методи стандартно-повторної вправи і 2) методи варіативної (перемінної) вправи.

Методи стандартно-повторної вправи відрізняються повторним виконанням заданих рухів, дій по ходу даного, окремого заняття без скільки-небудь істотних змін їхньої структури і зовнішніх параметрів навантаження (повторне пробігання якої-небудь стандартної дистанції з постійною швидкістю, багаторазове піднімання штанги тієї самої ваги тим самим способом і т.п.). Така стандартизація — одна

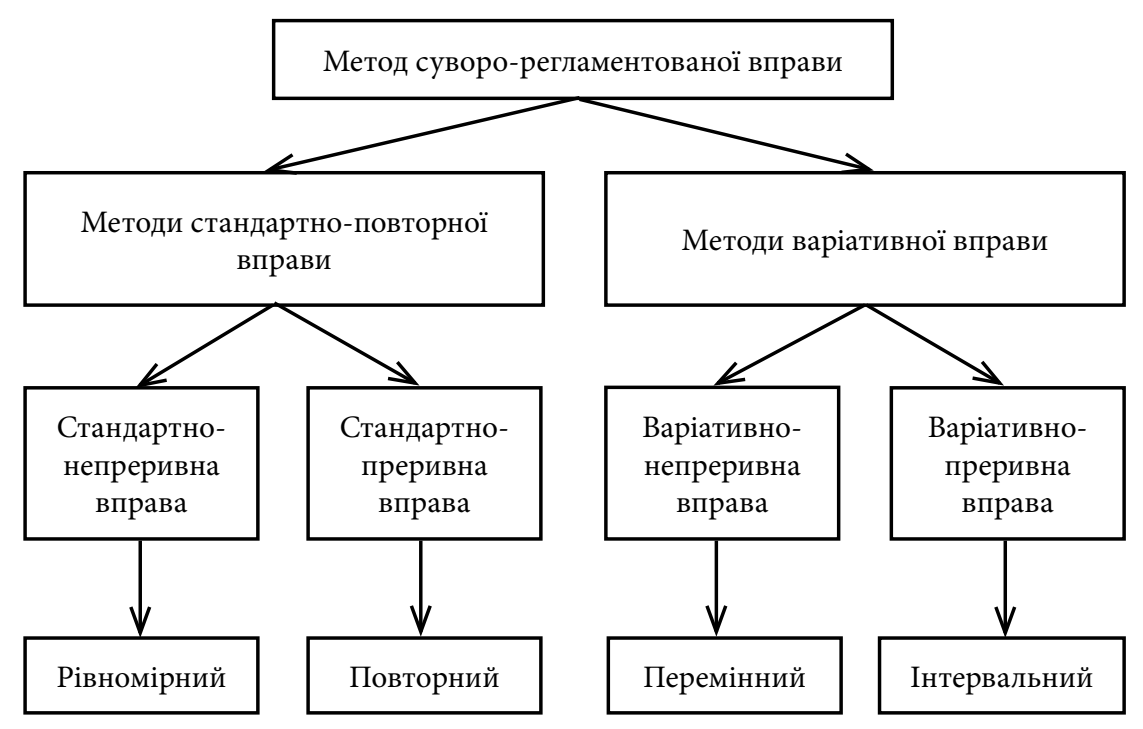

Рис. 5.6. Класифікація методів суворо-регламентованої вправи 
Таблиця 1.

Класифікація методів фізичного виховання за рішенням освітніх завдань

\begin{tabular}{|c|c|c|c|c|}
\hline \multirow{2}{*}{$\begin{array}{l}\text { Група } \\
\text { вправ }\end{array}$} & \multirow{2}{*}{$\begin{array}{c}\text { Методи } \\
\text { фізичної впра- } \\
\text { ви }\end{array}$} & \multicolumn{3}{|c|}{ Типи інтервалів відпочинку між серіями вправ } \\
\hline & & ординарний & напружений & мінімакс \\
\hline \multirow[t]{3}{*}{$\begin{array}{l}\text { Основні } \\
\text { вправи }\end{array}$} & $\begin{array}{l}\text { Суворо-рег- } \\
\text { ламентованої } \\
\text { вправи }\end{array}$ & $\begin{array}{l}\text { Навчання ру- } \\
\text { ховим діям }\end{array}$ & $\begin{array}{l}\text { Удосконалення } \\
\text { та закріплення } \\
\text { рухових дій }\end{array}$ & - \\
\hline & Ігровий & $\begin{array}{l}\text { Удосконалення } \\
\text { та закріплення } \\
\text { рухових дій }\end{array}$ & $\begin{array}{l}\text { Удосконалення } \\
\text { та закріплення } \\
\text { рухових дій }\end{array}$ & - \\
\hline & Змагальний & $\begin{array}{l}\text { Удосконалення } \\
\text { та закріплення } \\
\text { рухових дій }\end{array}$ & $\begin{array}{l}\text { Удосконалення } \\
\text { та закріплення } \\
\text { рухових дій }\end{array}$ & - \\
\hline \multirow[t]{3}{*}{$\begin{array}{l}\text { Підвідні } \\
\text { вправи }\end{array}$} & $\begin{array}{l}\text { Суворо-рег- } \\
\text { ламентованої } \\
\text { вправи }\end{array}$ & $\begin{array}{l}\text { Оволодіння } \\
\text { підвідними } \\
\text { вправами }\end{array}$ & - & - \\
\hline & Ігровий & - & - & - \\
\hline & Змагальний & - & - & - \\
\hline \multirow[t]{3}{*}{$\begin{array}{l}\text { Підготовчі } \\
\text { вправи }\end{array}$} & $\begin{array}{l}\text { Суворо-рег- } \\
\text { ламентованої } \\
\text { вправи }\end{array}$ & $\begin{array}{l}\text { Координація } \\
\text { Сила } \\
\text { Гнучкість }\end{array}$ & Витривалість & Бистрота \\
\hline & Ігровий & $\begin{array}{l}\text { Прудкість } \\
\text { Координація } \\
\text { Сила } \\
\text { Гнучкість }\end{array}$ & Витривалість & - \\
\hline & Змагальний & $\begin{array}{l}\text { Прудкість } \\
\text { Координація } \\
\text { Сила } \\
\text { Гнучкість }\end{array}$ & Витривалість & - \\
\hline
\end{tabular}

Таблиця 2

Класифікація методів навчання на основі предметної інтерпретації

\begin{tabular}{|c|c|c|c|c|c|}
\hline Група вправ & Різновид вправ & Метод & $\begin{array}{c}\text { Деталізація ме- } \\
\text { тоду }\end{array}$ & $\begin{array}{c}\text { Тип інтервалів } \\
\text { відпочинку між } \\
\text { серіями вправ }\end{array}$ & $\begin{array}{c}\text { Предметна } \\
\text { інтерпретація } \\
\text { метода навчання }\end{array}$ \\
\hline \multirow[t]{5}{*}{ Основна } & \multirow[t]{3}{*}{ Цілісна } & $\begin{array}{l}\text { Суворо-регламентованої } \\
\text { вправи }\end{array}$ & Повторний & Ординарний & \multirow{3}{*}{$\begin{array}{l}\text { Метод цілісного нав- } \\
\text { чання }\end{array}$} \\
\hline & & Ігровий метод & & & \\
\hline & & Змагальний & & & \\
\hline & Розчленована & $\begin{array}{l}\text { Суворо-регламентованої } \\
\text { вправи }\end{array}$ & Повторний & Ординарний & $\begin{array}{l}\text { Метод розчленова- } \\
\text { ного навчання }\end{array}$ \\
\hline & $\begin{array}{l}\text { Компоненти ос- } \\
\text { новної вправи }\end{array}$ & $\begin{array}{l}\text { Суворо-регламентованої } \\
\text { вправи }\end{array}$ & Повторний & Ординарний & $\begin{array}{l}\text { Метод вирішення } \\
\text { окремих рухових за- } \\
\text { вдань }\end{array}$ \\
\hline Підвідна & Підвідні вправи & $\begin{array}{l}\text { Суворо-регламентованої } \\
\text { вправи }\end{array}$ & Повторний & Ординарний & $\begin{array}{l}\text { Метод } \\
\text { вправ }\end{array}$ \\
\hline \multirow[t]{5}{*}{ Підготовча } & Бистрота & \multirow{5}{*}{$\begin{array}{l}\text { Суворо-регламентованої } \\
\text { вправи }\end{array}$} & \multirow{5}{*}{ Повторний } & Мінімакс & \multirow{5}{*}{ Метод поєднання } \\
\hline & Координація & & & Ординарний & \\
\hline & Сила & & & Ординарний & \\
\hline & Витривалість & & & Напружений & \\
\hline & Гнучкість & & & Ординарний & \\
\hline
\end{tabular}


з необхідних умов формування і закріплення рухових навичок, а також морфофункциональної адаптації організму до визначеної діяльності і збереження досягнутого рівня працездатності.

Характерна риса методів варіативної (перемінної) вправи - спрямована зміна факторів, що впливають, по ходу вправи. Це досягається різними шляхами: шляхом прямої зміни параметрів рухів (швидкості, темпу, тривалості і т.д.), зміною способу виконання дій, шляхом варіювання інтервалів відпочинку і зовнішніх умов, додаткових обтяжень і т.д. Суть справи при цьому складається в пред'явленні організму нових, незвичайних і в кінцевому рахунку підвищених вимог для того, щоб стимулювати збільшення його функціональних можливостей. Одночасно, завдяки варіюванню форм і умов дій, пред'являються вимоги до динамічності засвоєних навичок, що сприяє розширенню діапазону регулювання рухів, утворенню рухових координацій, удосконалюванню самих навичок.

Непреривність і дискретність навантаження в методах вправи. За цією ознакою кожна 3 перерахованих груп методів суворо-регламентованої вправи може бути розділена на дві підгрупи: методи вправи в режимі непреривного (злитого) навантаження і методи вправи в режимі преривного (дискретного) навантаження.

Методи вправи в режимі непреривного навантаження характеризуються злитістю впливів, відпочинок надається лише по закінченні всього навантаження. Один з найбільш розповсюджених методів такого типу - рівномірний метод.

Інший не менш розповсюджений метод - nеремінний метод, також зв'язаний із тривалим непреривним виконанням рухів циклічного характеру, але $з$ перемінною швидкістю, яка змінюється протягом дистанції по заданій програмі.

Методи вправи в режимі преривного навантаження відрізняються системним чергуванням його порцій з нормованими інтервалами відпочинку в процесі виконання завдання.

У сполученні з стандартним чи варіативним навантаженням відповідно треба розрізняти методи повторної вправи і методи інтервальної вправи.

Комбіновані методи вправи. У практиці фізичного виховання можливі усілякі варіанти комбінування властивостей, що характеризують окремі методи: моменти стандартизації впливів можуть сполучатися в різному порядку з їхнім варіюванням, повторюваність навантаження - 3 його зміною, безперервність одних фаз вправи змінюватися інтервальною роботою і т.д.

В останній час широке застосування знайшли спеціальні методичні форми регламентації вправ у комплексному змісті заняття. Основна 3 них «кругове тренування».
Основу «кругового тренування» складає серійне (злите чи з інтервалами) повторення декількох видів фізичних вправ, підібраних і об'єднаних у комплекс відповідно до визначеної схеми. Вправи виконуються в порядку послідовного проходження 8-10 «станцій» (місць для кожного із них з відповідним устаткуванням), що розташовуються в залі чи на майданчику по колу, так щоб шлях через них утворював замкнутий контур. На кожній «станції» повторюється один вид рухів чи дій (присідання з обтяженням, віджимання в упорі, підтягування, нахили і т.д.). Більшість 3 них звичайно має відносно локальну чи регіональну спрямованість, тобто впливає переважно на визначену м'язову групу (м'язи нижніх кінцівок, поясу верхніх кінцівок, передньої чи задньої поверхні тіла), але $є$, як правило, i $1-2$ вправи загального впливу. Число повторень на кожній «станції» встановлюють індивідуально, у залежності від показників так називаного максимального тесту (МТ) чи «повторного максимуму» (ПМ) - попереднього іспиту на доступне граничне число повторень (часто як тренувальну норму беруть «1/2» чи «2/3» $\mathrm{MT})$.

У комплекси «кругового тренування» включають у більшості випадків технічно порівняно нескладні і попередньо добре розучені рухи, головним чином $з$ числа засобів загальнопідготовчої і спортивно-допоміжної гімнастики, а також з важкої і легкої атлетики і деякі інші. Хоча переважна частина цих рухів має ациклічну структуру, у ряді варіантів «кругового тренування» їм додають штучно циклічний характер шляхом злитих повторень і в такий спосіб дозують по типу циклічної роботи. Ввесь «круг» проходять в окремому занятті від 1 до 3 разів разом чи інтервально (у залежності від методу, що обирається), дозуючи загальний час проходження, інтервали відпочинку (якщо вони є) і число повторень.

\section{Ігровий і змагальний методи}

Ігровий метод. Значення гри як різноманітного суспільного явища, узагалі говорячи, виходить далеко за сферу фізичного виховання і навіть виховання в цілому. Виникнувши на ранніх етапах історії і розвиваючись разом із усією культурою суспільства, гра служила і служить задоволенню різних потреб - у самопізнанні і спілкуванні, у духовному і фізичному розвитку, у відпочинку і розвазі і т.д. Одна з головних функцій гри - педагогічна: гра здавна $\epsilon$ одним із основних засобів і методів виховання в широкому розумінні слова.

Поняття ігрового методу в сфері виховання відбиває методичні особливості гри, тобто те, що відрізняє ії в методичному відношенні (за особли- 
востями організації діяльності учнів, керівництва нею й іншими педагогічно істотними ознаками) від інших методів виховання. При цьому ігровий метод не обов'язково зв'язаний лише з якими-небудь загальноприйнятими іграми, наприклад футболом, чи волейболом елементарними рухливими іграми. У принципі він може бути застосований на матеріалі будь-яких фізичних вправ, за умови, звичайно, що вони піддаються організації відповідно до особливостей цього методу.

Основними методичними особливостями ігрового методу є (А.М. Максименко, 2001):

- забезпечення всебічного, комплексного розвитку рухових здібностей і удосконалення рухових умінь і навичок;

- наявність у грі елементів протиборства вимагає від особистості значних проявів рухових здібностей;

- широкий вибір різноманітних засобів досягнення мети, імпровізований характер дій у грі сприяє формуванню у людини самостійності, ініціативи, творчості та розвитку інших особистих якостей;

- додержання умов і правил гри дає можливість педагогу формувати моральні якості дитини: колективізм, почуття взаємодопомоги, дисциплінованість і т.п.;

- емоційність виконання фізичних вправ сприяє формуванню у дітей стійкої зацікавленості і позитивного мотиву до фізкультурних занять.

Ігровий метод використовується в процесі фізичного виховання не стільки для початкового навчання рухам чи вибіркового впливу на окремі здібності, скільки для комплексного удосконалювання рухової діяльності в ускладнених умовах. У найбільшій ступені він дозволяє удосконалювати такі якості і здібності, як спритність (координаційно-рухові і зв'язані з ними здібності), швидкість орієнтування, самостійність, ініціативність. У руках умілого фахівця він служить також дуже діючим методом виховання колективізму, товариства, свідомої дисципліни й інших моральних якостей особистості.

Змагальний метод. Змагальний метод у фізичному вихованні застосовується як у відносно елементарних формах, так і в розгорнутій формі. У першому випадку це виражається у використанні змагального початку як підпорядкованого елементу загальної організації заняття (як способу стимулювання інтересу й активізації діяльності у виконанні окремих вправ), у другому - у якості самостійної форми організації занять, підпорядкованій логіці змагальної діяльності (контрольно-залікові, офіційні спортивні і подібні їм змагання).

Основна, визначальна риса змагального методу - конкурентне зіставлення сил в умовах упорядко- ваного суперництва, боротьби за першість чи можливо високе досягнення. Звідси випливають і всі інші особливості цього методу.

Він дозволяє:

- стимулювати максимальний прояв рухових здібностей і визначити рівень їх розвитку;

- визначити і оцінити якість володіння руховими навичками;

- забезпечити максимальне фізичне навантаження;

- сприяти вихованню вольових якостей.

Змагальний метод застосовується у рішенні різноманітних педагогічних завдань: вихованні вольових і моральних якостей, розвитку рухових здібностей, удосконалюванні умінь і навичок, формуванні здатності раціонально використовувати їх в ускладнених умовах. У порівнянні з іншими методами фізичного виховання, він дозволяє пред'являти найбільш високі вимоги до функціональних можливостей організму і тим сприяти їх найвищому розвиткові. Винятково велике значення змагального методу й у вихованні моральних і вольових якостей: цілеспрямованості, ініціативності, рішучості, наполегливості, здатності переборювати труднощі, самовладання, самовідданості й ін.

\section{Висновки}

1. Функціональний підхід $є$ основою для створення системи методів, в якій вони виступають як відносно обособлені способи досягнення цілей фізичного виховання.

2. Методи, які використовуються у фізичному вихованні можуть бути розподілені на три групи: методи фізичної вправи, методи слова і методи показу.

3. Перспективним напрямком розвідок $\epsilon$ вивчення закономірностей проектування педагогічних технологій у фізичному вихованні.

\section{Список літератури}

1. Бабанский Ю.К Методы обучения в современной общеобразовательной школе. - М., 1985.

2. Данилов М.А., Есипов Б.П. Дидактика. - М., 1957.

3. Васьков Ю.В. Інструктивно-методичні рекомендації щодо підвищення якості уроку фізичної культури // Теорія та методика фізичної культури. - Харків: «ОВС», 2004. - № 2. - С. 20-27.

4. Клингберг Л. Проблемы теории обучения. М.: Педагогика, 1984. - $256 \mathrm{c}$

5. Лернер И.Я., Скаткин М.Н. О методах обучения // Советская педагогика. - 1965. - № 3.

6. Максименко А.M. Основы теории и методики физической культуры. - М.: 4-й филиал Воениздата, 2001. - С. 77-95. 
7. Матвеев Л.П. Теория и методика физической культуры: Учебник для институтов физической культуры. - М.: Физкультура и спорт, 1991. - С. 63-83.

8. Махмутов М.И. Проблемное обучение. Основные вопросы теории. - М.: Педагогика, 1975. - 368 c.

9. Паламарчук В.Ф. Школа учит мыслить. - 2-е изд., доп. и перераб. - М.: Просвещение, 1987. - 206 с.

10. Подласый И.П. Педагогика: Новый курс: Учеб. для студ. высш. учеб. заведений: В 2 ккн. - М.: Гуманит. изд. центр ВЛАДОС, 2003. - Кн. 1: Общие основы. Процесс обучения. -576 с.

11. Теория иметодика физического воспитания. Общие основы теории и методики физического воспитания:
Учебник в 2-х томах / Под редакцией Т.Ю. Круцевич. - Том 1. - К.: Олимпийская литература, 2003. - С. $111-135$.

12. Сергієнко Л.П. Практикум з теорії і методики фізичного виховання: Навч. посібник. - Харків: «ОВС», 2007. - C. 38-49.

13. Шиян Б.М. Теорія і методика фізичного виховання школярів: Навчальний посібник в 2-х частинах. - Т.: Навчальна книга - Богдан, 2001. - Ч. 1. - С. $138-166$.

14. Щукина Г.И. Педагогические проблемы формирования познавательных интересов учащихся. - М.: Просвещение, 1988. - 203 с.

Надійшла до редакиіï 15.01.2009

Худолей О.Н. Методы физического воспитания.

В статье рассматриваются общие подходы к определению классификации методов, которые используются в физическом воспитание. Дана характеристика методу физического упражнения.

Ключевые слова: метод, метод физического упражнения, строго-регламентированного упражнения, состязательный и игровой.

Houdoliy O.M. Methods of physical education.

In article general approaches are considered to determination of classification of methods, which are used in the physical education. Given description of method of physical exercise.

Keywords: method, method of physical exercise, strict-regulated exercise, competition and playing.

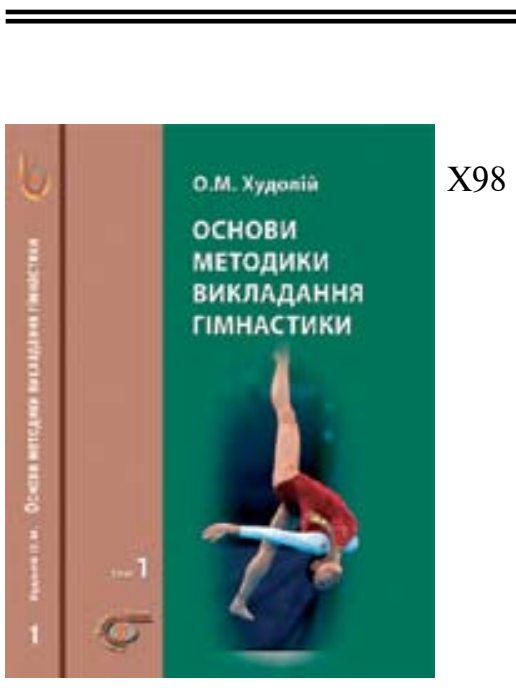

\section{9lobа книжка}

\section{Худолій О.М.}

Основи методики викладання гімнастики: Навч. посібник. У 2-х томах. - 4-е вид., випр. і доп. - Харків: «ОВС», 2008. - Т. 2. - 464 с: іл.

ISBN 966-7858-55-1.

У навчальному посібнику розглянута методика викладання гімнастики в школі і ДЮСШ, а також методика організації і проведення змагань зі спортивної гімнастики.

Посібник рекомендовано викладачам і студентам факультетів фізичного виховання вищих педагогічних навчальних закладів III-IV рівня акредитації та вчителям фізичної культури середніх загальноосвітніх шкіл.

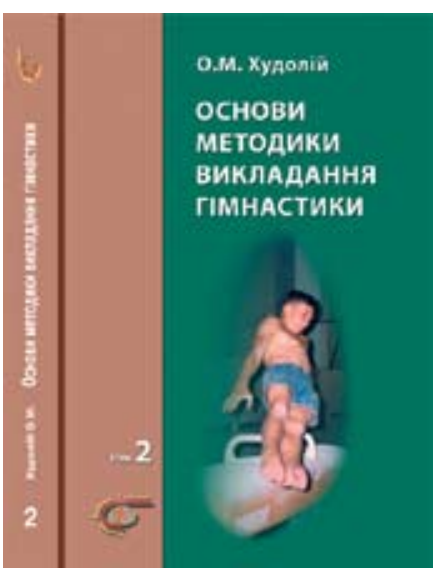

X98

\section{Худолій О.М.}

Основи методики викладання гімнастики: Навч. посібник. У 2-х томах. - 4-е вид., випр. і доп. - Харків: «ОВС», 2008. - Т. 2. - 464 с: іл.

ISBN 966-7858-54-5.

ISBN 966-7858-56-1(II).

У навчальному посібнику розглянута методика викладання гімнастики в школі і ДЮСШ, а також методика організації і проведення змагань зі спортивної гімнастики.

Посібник рекомендовано викладачам і студентам факультетів фізичного виховання вищих педагогічних навчальних закладів III-IV рівня акредитації та вчителям фізичної культури середніх загальноосвітніх шкіл.

\section{Рекомендовано}

Міністерством освіти і науки України як навчальний посібник для студентів вищих навчальних закладів (лист № 14/18.2-1928 від 17.11.03) 